\title{
Penggunaan Molagen untuk Meningkatkan Produksi dan Kadar Kurkumin Tanaman Kunyit (Curcuma domestica val)
}

\author{
(The Uses of Molagen to Increase the Production and \\ the Currumin Content of Turmeric Plants (Curcuma domestica Val))
}

\author{
Agustinus Maru Bata, Amir Hamzah \\ Universitas Tribhuwana Tunggadewi \\ `Corresponding author email: amir.hamzah@unitri.ac.id
}

\begin{abstract}
The Improvement of the soil could be increase the productivity of turmeric productions and curcumin levels. It could be done in various ways. One of them uses coconut husks and nitrogen fertilizers. The uses of coconut husks in liquid form is believed to be able to increase potassium levels in the soil. Likewise, the availability of sufficient nitrogen will be able to increase plant growth so that curcumin levels will increase. This study aims to obtain the right doses of Molagen for the growth and production of turmeric plants, as well as to increase curcumin levels. This research was conducted in Tlogomas village, Malang city at an altitude of $\pm 450 \mathrm{~m}$ above sea level. This study used a Randomized Block Design with 3 replications, with 2 factors. Factor 1. Molagen Dose $(M):$ MO = Control (without Molagen), $M 1=$ Molagen $100 \mathrm{ml} /$ plant, $M 2=$ Molagen $200 \mathrm{ml} /$ plant, $M 3=$ Molagen 300 $\mathrm{ml} / \mathrm{plant}$, M4 = Molagen $500 \mathrm{ml} /$ plant. Factor 2. Dosage of Urea Fertilizer $(U): U 1=$ Urea Dose $100 \mathrm{~kg} / \mathrm{ha}, \mathrm{U} 2=$ Urea Doses $200 \mathrm{~kg} / \mathrm{ha}, \mathrm{U} 3=$ Urea Doses $300 \mathrm{~kg} / \mathrm{ha}$. Parameters observed included: plant height, leaf area, wet weight, and curcumin content. The results of subsequent observations were analyzed by ANOVA to determine the effect of each treatments. The results showed that the use of molagen with various doses of urea was able to increase height growth of the plants, leaf areas, Stover weights and rhizome weights. Curcumin levels obtained on average between $2.2-2.7 \%$.
\end{abstract}

Keywords: curcumin; molagen; tumeric plant

\begin{abstract}
Abstrak: Perbaikan produktivitas tanah untuk meningkatkan produksi kunyit dan kadar kurkumin dapat dilakukan dengan berbagai cara. Salah satunya adalah penggunaan sabut kelapa dan pupuk nitrogen. Penggunaan sabut kelapa dalam bentuk cair diyakini mampu meningkatkan kadar kalium dalam tanah. Begitu juga ketersediaan nitrogen yang cukup akan mampu meningkatkan pertumbuhan tanaman sehingga kadar kurkumin akan meningkat. Penelitian ini bertujuan untuk mendapatkan dosis Molagen yang tepat untuk pertumbuhan dan produksi tanaman kunyit, serta kadar kurkumin. Kadar kurkumin dianalisis dengan spektrometer. Penelitian ini dilaksanakan di kelurahan Tlogomas kota Malang pada ketinggian $\pm 450 \mathrm{~m}$ dpl. Penelitian ini menggunakan Rancangan Acak Kelompok dengan dua faktor dan tiga ulangan. Faktor pertama dosis Molagen (M) : M0 = Kontrol (tanpa Molagen), M1 = Molagen $100 \mathrm{ml} / \mathrm{tanaman}, \mathrm{M} 2$ = Molagen $200 \mathrm{ml} /$ tanaman, M3 = Molagen $300 \mathrm{ml} / \mathrm{tanaman}, \mathrm{M} 4=$ Molagen $500 \mathrm{ml} /$ tanaman. Faktor kedua, dosis pupuk Urea (U) : U1 = Dosis Urea $100 \mathrm{~kg} / \mathrm{ha}, \mathrm{U} 2=$ Dosis Urea 200 $\mathrm{kg} / \mathrm{ha}$, U3 = Dosis Urea $300 \mathrm{~kg} / \mathrm{ha}$. Hasil penelitian menunjukan bahwa penggunaan Molagen dan berbagai dosis urea mampu meningkatkan pertumbuhan tinggi tanaman, luas daun, berat brangkasan dan bobot rimpang. Kadar kurkumin yang diperoleh rata-rata antara $2,2-2,7 \%$.
\end{abstract}

Kata kunci: molagen; kurkumin; tanaman kunyit

\section{PENDAHULUAN}

Kunyit termasuk jenis tanaman herbal yang sangat dicari saat ini seiring dengan merebaknya pandemik Covid-19. Kunyit juga termasuk salah satu komoditas ekspor yang untuk bahan baku industri farmasi. Selain untuk kebutuhan ekspor, kebutuhan dalam negeri juga peningkatan terutama untuk industri obat tradisional, serta kebutuhan rumah tangga. Kandungan kurkuminoid terdapat di dalam tanaman biofarmaka termasuk tanaman kunyit sangat bermanfaat untuk kesehatan tubuh. Kurkuminoid merupakan kelompok senyawa fenolik yang manfaatnya untuk mencegah infeksi dari penyakit (Kristina et al, 2007). Beberapa peneliti melaporkan bahwa kandungan kurkuminoid adalah kurkumin yang warnanya kuning. Kandungan kurkumin yang dijumpai cukup tinggi juga terdapat pada kunyit, berkisar $3-4 \%$ (Joe et al., 2004), sedangkan Aan (2004), memperoleh kandungan kurkumin sebesar 2,43\%.

Kandungan kurkumin sebenarnya masih bisa ditingkatkan, karena permintaan tanaman biofarmaka yang memiliki kadar kurkumin tinggi cukup diminati untuk 
kebutuhan industri farmasi. Permintaan ini belum dibarengi dengan peningkatan produktivitas tanaman yang dimiliki. Salah satu faktor yang mengakibatkan berkurangnya produksi adalah teknologi budidaya. Sebagai upaya untuk mendapatkan produksi tanaman kunyit adalah dengan menggunakan mikroba yang berasal dari potensi sumberdaya lokal yang mengandung kadar $\mathrm{P}$ tinggi. Potensi itu terdapat pada limbah sabut kelapa. Sabut kelapa mengandung beberapa unsur yang dapat digunakan sebagai pupuk alternatif. Wijaya $e t$ al, (2017), sabut kelapa mengandung beberapa unsur seperti K, P, Ca, Mg dan Na. Kalium dari sabut kelapa dapat diperoleh melalui perendaman. Air rendaman ini sering kita sebut sebagai pupuk organic cair (POC). POC ini sangat baik diberikan sebagai pengganti pupuk $\mathrm{KCl}$ untuk tanaman (Sari, 2015). Pupuk organik cair merupakan larutan hasil fermentasi dari bahan-bahan organik baik, tanaman, hewan maupun kotoran manusia. Dalam satu buah kelapa terdapat 0,4 $\mathrm{kg}$ serabut mengandung 20\%-30\% kalium. Rahma (2019), sabut kelapa mengandung $\mathrm{K} 2 \mathrm{O}$ sebesar 2,48\% sehingga dapat dimanfaatkan sebagai pupuk organik cair. Selain itu di dalam sabut kelapa juga mengandung unsur hara makro dan mikro untuk pertumbuhan tanaman.

Upaya untuk mendapatkan kandungan kalium secara cepat adalah menggunakan mikroorganisme lokal (Mol) berbahan dasar sabut kelapa ditambahkan dengan nitrogen. Potensi penggabungan kedua unsur ini disebut sebagai "Molagen". Molagen adalah istilah untuk mikroorganisme lokal berbahan dasar sabut kelapa dengan penambahan nitrogen. Penggunaan $\mathrm{K}$ yang dikombinasi dengan nitrogen seperti yang terdapat dalam molagen akan meningkatkan pertumbuhan tanaman kunyit. Kandungan $\mathrm{K}$ yang tersedia di tanah akan mempengaruhi kelembutan tekstur rimpang. Semakin tinggi kalium yang diberikan, semakin tinggi pula kadar serat rimpang. Hal ini akan membuat dinding sel rimpang semakin kuat (Sanyal dan Dhar, 2006). Selanjutnya dapat meningkatkan daya tahan rimpang terhadap serangan hama dan penyakit serta meningkatkan kadar kurkumin dalam jahe. Penelitian ini bertujuan untuk mendapatkan dosis penggunaan mol sabut kelapa dan nitrogen (Molagen) yang tepat untuk pertumbuhan dan produksi tanaman kunyit serta kadar kurkumin yang tinggi.

\section{METODE}

Penelitian ini dilaksanakan di kelurahan Tlogomas kota Malang pada ketinggian 450 $\mathrm{m}$ dpl. Peralatan yang digunakan meliputi : Polybag ukuran $10 \mathrm{~kg}$, gembor, drum plastik ukuran besar untuk pembuatan mol, gelas ukur, timbangan analitik, , penggaris, kamera dan alat tulis. Bahan yang digunakan meliputi bibit tanaman kunyit, limbah sabut kelapa, EM4, molases, pupuk Urea, TSP, dan $\mathrm{KCl}$, tanah, dan pupuk kandang.

Penelitian ini menggunakan menggunakan Rancangan Acak Kelompok (RAK) dengan 2 faktor. Kedua faktor tersebut diuraikan sebagai berikut:

Faktor 1. Dosis Molagen (K) : $\mathrm{M} 0=$ Kontrol (tanpa Molagen) M1 = Molagen $100 \mathrm{ml} /$ tanaman, $\mathrm{M} 2=$ Molagen 200 $\mathrm{ml} / \mathrm{tanaman}, \quad \mathrm{M} 3=$ Molagen 300 $\mathrm{ml} /$ tanaman, $\mathrm{M} 4=$ Molagen 500 $\mathrm{ml} /$ tanaman, Faktor 2. Dosis Pupuk Urea (U) : U1 = Dosis Pupuk Urea $100 \mathrm{~kg} / \mathrm{ha}, \mathrm{U} 2$ = Dosis Pupuk Urea $200 \mathrm{~kg} / \mathrm{ha}, \mathrm{U} 3$ = Dosis Pupuk Urea $300 \mathrm{~kg} / \mathrm{ha}$. Percobaan ini diulang sebanyak 3 kali, masing-masing perlakuan terdiri dari 3 polybag, sehingga keseluruhan percobaan berjumlah $5 \times 3 \times 3$ x $3=135$ polybag percobaan.

Parameter yang diamati meliputi: tinggi tanaman, luas daun, diameter batang, jumlah anakan, berat basah umbi dan kadar kurkumin. Kadar kurkumin dianalisa dengan menggunakan spektrometer. Data hasil pengamatan kemudian dianalisis ragam taraf $5 \%$ dan $1 \%$ untuk mengetahui pengaruh perlakuan. Jika ada yang menunjukan perbedaan nyata akan dilanjutkan dengan uji beda BNT pada taraf nyata $5 \%$. 


\section{HASIL DAN PEMBAHASAN}

\section{Tinggi Tanaman}

Hasil penelitian menunjukan bahwa penggunaan dosis molagen dan urea terhadap pertumbuhan tinggi tanaman kunyit sampai pada umur 140 HST tidak menunjukan adanya interaksi antara perlakuan. Pengamatan tinggi tanaman disajikan pada tabel 1.

Tabel 1. Pengaruh pemberian dosis molagen terhadap pertumbuhan tinggi tanaman kunyit

\begin{tabular}{lccccc}
\hline \multirow{2}{*}{ Perlakuan } & \multicolumn{5}{c}{ Hari Setelah Tanam (HST) } \\
\cline { 2 - 6 } Kontro & 28 & 56 & 84 & 112 & 140 \\
\cline { 2 - 6 } Molagen $100 \mathrm{ml} / \mathrm{tnm}$ & 54.39 & 81.15 & 108.2 & $112.63 \mathrm{a}$ & $117.93 \mathrm{a}$ \\
Molagen $200 \mathrm{ml} / \mathrm{tnm}$ & 55.51 & 83.19 & 111.9 & $115.74 \mathrm{~b}$ & $121.00 \mathrm{ab}$ \\
Molagen $300 \mathrm{ml} / \mathrm{tnm}$ & 51.62 & 84.33 & 112.7 & $121.39 \mathrm{c}$ & $120.30 \mathrm{ab}$ \\
Molagen500 ml/tnm & 56.07 & 85.59 & 110.7 & $120.37 \mathrm{bc}$ & $132.30 \mathrm{c}$ \\
\hline BNt 5\% & tn & tn & tn & $124.63 \mathrm{~d}$ & $125.07 \mathrm{~b}$ \\
\hline Urea 100 kg/ha & 53.59 & 82.69 & 110.9 & $116.73 \mathrm{a}$ & 12.65 \\
Urea 200 kg/ha & 53.62 & 85.19 & 113.5 & $121.93 \mathrm{~b}$ & 124.71 \\
Urea 300 kg/ha & 55.7 & 83.28 & 111.6 & $119.63 \mathrm{a}$ & 125.16 \\
\hline BNt 5\% & tn & tn & tn & 2.75 & tn \\
\hline
\end{tabular}

Keterangan: Angka yang diikuti huruf pada kolom dan baris yang sama menunjukan tidak beda nyata pada taraf $5 \%$

Tabel 1 menunjukan bahwa pertumbuhan tanaman pada umur 28, 56 dan 84 HST tidak menunjukan perbedaan nyata antar pelakuan. Pada umur 112 dan 140 HST barulah terlihat adanya perbedaan pertumbuhan tinggi tanaman pada dosis 300 dan $500 \mathrm{ml} /$ tanaman. Hal ini menunjukan bahwa molagen yang dibuat dari bahan baku sabut kelapa efektif untuk meningkatkan pertumbuhan tanaman kunyit. Penggunaan dosis urea pada penelitian ini berbeda nyata pada umur 112 bulan setelah tanam, sedangkan pada umur 26, 56 dan 140 HST tidak berbeda nyata. Hal ini menunjukan bahwa penyerapan nitrogen efektif pada umur 112 HST sehingga mempengaruhi pertumbuhan tinggi tanaman. Pada umur 140 HST tinggi tanaman tidak berbeda nyata karena diduga pada umur 140 HST sudah memasuki fase generatif sehingga tidak berpengaruh lagi terhadap pertumbuhan tinggi tanaman.

Penggunaan mol sabut kelapa sebagai pemasok kalium dan urea sebagai penyedia nitrogen mampu meningkatkan pertumbuhan tanaman kunyit. Sabut kelapa merupakan limbah organik yang potensial sebagai penambah unsur hara dalam tanah. Unsur kalium yang terkandung dalam sabut kelapa sekitar 10-20 \%. Kalium merupakan hara esensial yang dibutuhkan tanaman sebagai aktivator dari beberapa enzim untuk fotosintesis dan meningkatkan asimilasi $\mathrm{CO} 2$. Hasil fotosintesis ini selanjutnya ditranslokasi ke bagian-bagian tanaman (Rahmawan et al., 2019).

\section{Luas Daun}

Luas daun tanaman kunyit pada semua umur pengamatan dari umur 28, sampai 149 HST menunjukkan adanya perbedaan signifikan. Pada umur tanaman 56, 84, 112 dan 140 penggunaan dosis molagen yang efektif pada dosis $300 \mathrm{ml} /$ tanaman. Pemberian dosis urea pada penelitian ini terlihat bahwa pada umur 28 HST tidak berbeda nyata, namun pada umur 56, 84, 112 dan 140 menunjukan perbedaan nayata (Tabel 2).

Dosis urea sebanyak $200 \mathrm{~kg} / \mathrm{ha}$ sangat efektif untuk tanaman kunyit. Dengan demikian maka penggunaan molagen yang mengandung unsur kalium dan nitrogen sangat efektif untuk pertumbuhan tanaman kunyit. Amanullah et al, (2016), Selain N unsur $\mathrm{K}$ juga memiliki peran yang cukup besar. Li et al., (2010), Kalium memiliki 
peran penting terhadap produktivitas tanaman

meningkatkan pertumbuhan dan produksi jahe. Penggunaan dosis $225 \mathrm{~kg} / \mathrm{ha}$ rimpang sampai mencapai $24,7 \%$.

Tabel 2. Pengaruh pemberian dosis molagen terhadap luas daun tanaman kunyit

\begin{tabular}{llllll}
\hline \multirow{2}{*}{ Perlakuan } & \multicolumn{5}{c}{ Hari Setelah Tanam (HST) } \\
\cline { 2 - 6 } Kontrol & 28 & 56 & 84 & 112 & 140 \\
\cline { 2 - 6 } Molagen $100 \mathrm{ml} / \mathrm{t}$ & $9.17 \mathrm{a}$ & $10.59 \mathrm{a}$ & $12.08 \mathrm{a}$ & $12.55 \mathrm{a}$ & $12.57 \mathrm{a}$ \\
Molagen $200 \mathrm{ml} / \mathrm{t}$ & $10.67 \mathrm{~d}$ & $11.42 \mathrm{~d}$ & $13.58 \mathrm{~b}$ & $13.41 \mathrm{~b}$ & $13.42 \mathrm{~b}$ \\
Molagen $300 \mathrm{ml} / \mathrm{t}$ & $9.42 \mathrm{ab}$ & $12.04 \mathrm{e}$ & $14.81 \mathrm{bc}$ & $13.43 \mathrm{bc}$ & $13.46 \mathrm{bc}$ \\
Molagen $500 \mathrm{ml} / \mathrm{t}$ & $10.12 \mathrm{c}$ & $11.07 \mathrm{c}$ & $13.97 \mathrm{c}$ & $13.82 \mathrm{~b}$ & $14.33 \mathrm{c}$ \\
\hline BNt $5 \%$ & 0.39 & 0.21 & 0.32 & 0.53 & 0.54 \\
\hline Urea $100 \mathrm{~kg} / \mathrm{h}$ & 9.58 & $10.33 \mathrm{a}$ & $13.15 \mathrm{a}$ & $12.76 \mathrm{a}$ & $12.78 \mathrm{a}$ \\
Urea $200 \mathrm{~kg} / \mathrm{h}$ & 9.9 & $10.83 \mathrm{~b}$ & $14.02 \mathrm{~b}$ & $14.22 \mathrm{~b}$ & $13.36 \mathrm{~b}$ \\
Urea 300 kg/h & 9.78 & $10.69 \mathrm{~b}$ & $13.30 \mathrm{ab}$ & $12.78 \mathrm{ab}$ & $12.93 \mathrm{ab}$ \\
\hline BNt 5\% & $\mathrm{tn}$ & 0.13 & 0.19 & 0.39 & 0.33 \\
\hline
\end{tabular}

Keterangan: Angka yang diikuti huruf pada kolom dan baris yang sama menunjukan tidak beda nyata pada taraf $5 \%$

Beberapa unsur penting yang berperan dalam pertumbuhan tanaman termasuk kalium dan nitrogen karena mempengaruhi fotosintesis dalam pembentukan klorofil, dan pembentukan karbohidrat (Hafsi et al, 2014). Total akumulasi kalium akan mencapai maksimum pada saat tanaman menjelang fase generatif. Kebutuhan kalium akan meningkat menjelang fase generatif atau sekitar 75\% dari total $\mathrm{K}$ yang diserap (Alfian \&
Purnawati, 2019).

\section{Bobot Brangkasan dan Bobot Rimpang}

Hasil pengamatan berat brangkasan menunjukan bahwa terjadi perbedaan nyata antar perlakuan baik pada perlakuan dosis molagen maupun perlakuan dosis urea (Tabel $3)$.

Tabel 3. Pengaruh pemberian dosis molagen terhadap bobot brangkasan dan bobot rimpang

\begin{tabular}{lcc}
\hline \multirow{2}{*}{ Perlakuan ml/ha } & \multicolumn{2}{c}{ Bobot Komponen Produksi } \\
\cline { 2 - 3 } & Bobot Brangkasan & Bobot Rimpang \\
\hline Kontrol & $399.93 \mathrm{a}$ & $129.52 \mathrm{a}$ \\
Molagen $100 \mathrm{ml} / \mathrm{t}$ & $580.52 \mathrm{~b}$ & $237.56 \mathrm{~b}$ \\
Molagen $200 \mathrm{ml} / \mathrm{t}$ & $665.63 \mathrm{c}$ & $294.74 \mathrm{c}$ \\
Molagen $300 \mathrm{ml} / \mathrm{t}$ & $616.67 \mathrm{~d}$ & $379.81 \mathrm{~d}$ \\
Molagen $500 \mathrm{ml} / \mathrm{t}$ & $843.52 \mathrm{e}$ & $444.78 \mathrm{e}$ \\
\hline BNt 5\% & 5.69 & 4.51 \\
\hline Urea 100 kg/ha & $540.78 \mathrm{a}$ & $227.49 \mathrm{a}$ \\
Urea 200 kg/ha & $608.93 \mathrm{~b}$ & $271.91 \mathrm{~b}$ \\
Urea 300 kg/ha & $714.04 \mathrm{c}$ & $269.58 \mathrm{~b}$ \\
\hline BNt 5\% & 5.00 & tn \\
\hline
\end{tabular}

Keterangan: Angka yang diikuti huruf pada kolom dan baris yang sama menunjukan tidak beda nyata pada taraf $5 \%$

Tabel 3 menunjukan bahwa penggunaan dosis molagen pada dosis $500 \mathrm{ml} /$ tanaman memiliki bobot brangkasan tertinggi yaitu sebesar $843.52 \mathrm{~g}$ dibandingkan dengan dosis lain. Bobot brangkasan terendah terdapat pada perlakuan kontrol yaitu sebesar 399,93 g. Perbedaan yang sama terlihat pada perlakuan penggunaan dosis urea. Bobot 
brangkasan tertinggi terdapat pada dosis urea $300 \mathrm{~kg} \mathrm{ha}^{-1}$ yaitu sebesar 714,04 g, namun tidak berbeda nyata dengan dosis $200 \mathrm{~kg} / \mathrm{ha}$ yaitu sebesar 806,93 g. Hal yang sama terlihat pada parameter bobot rimpang, dimana bobot rimpang tertinggi terdapat pada perlakuan dosis molagen sebesar $500 \mathrm{ml} / \mathrm{t}$. Bobot rimpang diperoleh sebesar 444,78 g, sedangkan terendah terdapat pada perlakuan kontrol yaitu sebesar 129,52g. Perlakuan pemberian dosis urea terlihat bahwa penggunaan dosis $200 \mathrm{~kg}$ urea ha ${ }^{-1}$ tidak berbeda nyata dengan dosis $300 \mathrm{~kg} / \mathrm{ha}$. Dengan demikian maka dosis urea terbaik untuk bobot brangkasan dan rimpang terdapat pada dosis urea $200 \mathrm{~kg} \mathrm{ha}^{-1}$.

Penggunaan molagen dan urea untuk tanaman kunyit terbukti efektif dalam meningkatkan pertumbuhan tanaman. Hal ini karena molagen yang digunakan mengandung unsur kalium dan nitrogen yang berfungsi untuk meningkatkan pertumbuhan tanaman. Li et al., (2010) mengemukakan bahwa penggunaan pupuk KCL berpengaruh terhadap pertumbuhan tanaman dan hasil fotosintesis. Hasil fotosintesis berupa pati selanjutnya ditranslokasikan ke bagian vegetatif tanaman (Rahmawan et al., 2019).

Beberapa peneliti mengungkapkan bahwa sabut kelapa memiliki kandungan yang dapat digunakan bioaktivator dan pupuk kalium. Pemberian konsentrasi dengan dosis yang tepat akan meningkatkan pertumbuhan dan hasil tanaman (Umar et al, 2021). Di dalam mol sabut kelapa mengandung berbagai macam unsur, termasuk kalium untuk pertumbuhan tanaman.

Pembuatan pupuk cair dengan unsur utama kalium dari bahan baku sabut kelapa memberikan dampak positif terhadap pertumbuhan (Wijaya et al, 2017)). Abu sabut kelapa juga mengandung KTK sebesar 20,72 cmol kg-1 sehingga efektif untuk tanaman, jika dibandingkan dengan bahan lain seperti kayu yang hanya 3,47 $\mathrm{cmol} \mathrm{kg-}^{-}$, dan sekam padi $16,70 \mathrm{cmol} \mathrm{kg}^{-1}$. Abu sabut kelapa memiliki total luas permukaan yang besar dibandingkan bahan-bahan lainnya sehingga permukaan yang mungkin melakukan pertukaran kation menjadi lebih banyak. Kadar air abu sabut kelapa sebesar $29,63 \%$ lebih tinggi dibandingkan standar mutu sebesar $15-25 \%$. Hal ini berkaitan dengan sifat sabut kelapa yang mudah menyerap dan menyimpan air (Lestari, 2016) ; Mamondol dan Bunga, 2017).

Dalam kaitan dengan penggunaan sabut kelapa sebagai mikroorganisme lokal sangat besar manfaatnya. Bahan tersebut juga dapat dibuat dalam bentuk cair. Bahan cair ini dapat dijadikan sebagai bahan activator karena terdapat mikroorganisme yang berfungsi untuk mempercepat tersedianya hara untuk tanaman. (Novianto et al, (2020), sabut kelapa yang difermentasi untuk POC mampu memperbaiki pertumbuhan tanaman. Kandungan hara yang dihasil dari fermentasi sabut kelapa sebagai POC berupa N, P dan K yang berfungsi untuk pertumbuhan tanaman. Sabut kelapa mengandung hara berupa $\mathrm{N}$ (0,44\%), P (119 $\left.\mathrm{mg} \mathrm{kg}^{-1}\right), \mathrm{K}(67,20 \mathrm{me} / 100 \mathrm{~g})$, $\mathrm{Ca}(7,73 \mathrm{me} / 100 \mathrm{~g}) \mathrm{Mg}(11,03 \mathrm{me} / 100 \mathrm{~g})$. Jamila dan Marni (2013) mendapatkan komposisi kandungan hara dari limbah sabut kelapa antara lain air 53,83\%, N 0,28\% ppm, P 0,1 ppm, K 6,726 ppm, Ca 140 ppm, dan $\mathrm{Mg} 170$ ppm. Dengan demikian maka, penggunaan MOL dari sabut kelapa yang dikombinasi dengan pupuk nitrogen mampu meningkatkan pertumbuhan tanaman dan kualitas hasil tanaman kunyit.

\section{Kadar Kurkumin}

Hasil analisa kadar kurkumin menunjukan bahwa penggunaan molagen dan urea mampu meningkatkan kadar kurkumin pada tanaman kunyit (Gambar 1). Hal ini menunjukan bahwa sebenarnya kadar kurkumin dapat ditingkat dengan penggunaan pupuk. Hasil analisis kadar kurkumin pada berbagai dosis molagen disajikan pada gambar 1.

Hasil tertinggi diperoleh diperoleh pada perlakuan M2U1, M2U2 dan M2U3 masingmasing $2,21 \%, 2,30 \%$ dan $2,71 \%$. Hasil ini menunjukan bahwa penggunaan dosis molagen sebesar $200 \mathrm{ml} /$ tanaman dengan tambahan berbagai dosis urea belum mampu meningkatkan kadar kurkumin pada tanaman kunyit. 

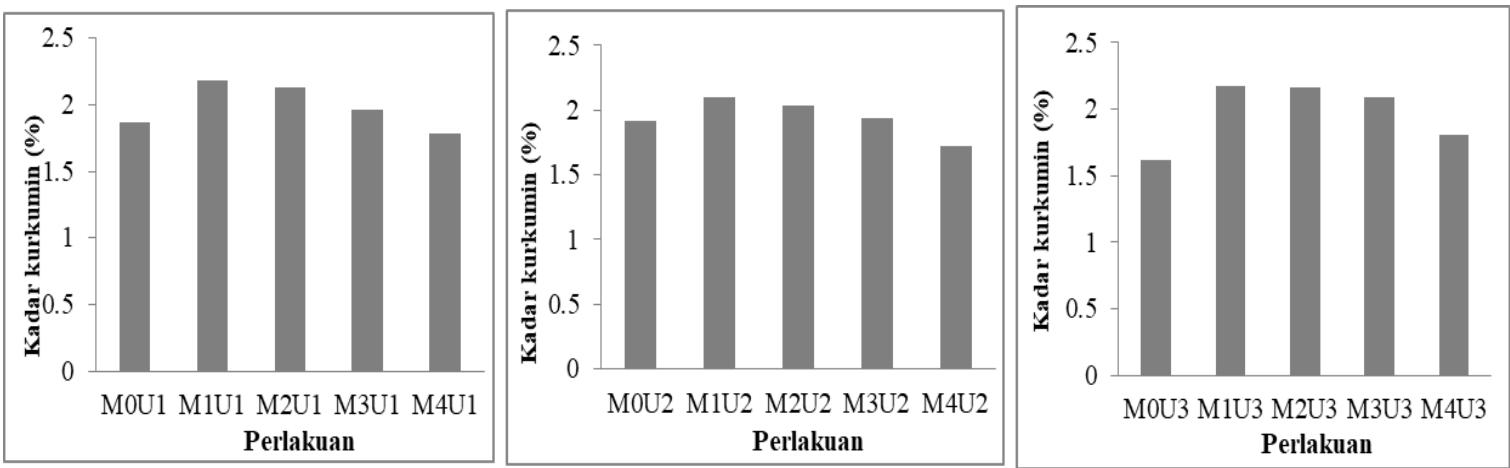

Gambar 1. Hasil analisis kadar kurkumin

Hasil yang diperoleh dari penelitian ini masih berada dibawah hasil yang diperoleh Joe et al (2004) yaitu antar 3-4\%. Namun hasil ini masih lebih baik dibandingkan dengan yang diperoleh Aan (2004) yang hanya sekitar 2,43\%. Rendahnya kadar kurkumin yang dicapai pada penelitian ini karena diduga berkaitan dengan waktu panen yang dilakukan yang hanya 6 bulan. Panen dipercepat pada umur 6 bulan karena kondisi tanaman yang sebagian sudah mengalami serangan penyakit.

Menurut Kristina et al., (2007) untuk mendapatkan hasil yang tinggi serta kadar kurkumin yang tinggi, tanamn kunyit dipanen pada umur 8-12 bulan. Idealnya tanaman zingeberaceae yang menghasilkan kadar kurkumin tinggi dipanen pada umur matang. Kurkumin merupakan metabolit sekunder yang terkandung di dalam tanaman yang masuk famili Zingiberaceae. Kurkumin memiliki khasiat sebagai anti imflamatori, anti imunodefisiensi, anti virus (virus flu burung), anti bakteri, anti jamur, antioksidan, anti karsinogenik (Kristina et al, 2007)

Kurkumin memiliki warna kuning tidak mudah larut dalam air, bersifat non toksik. Berkhasiat untuk mencegah penyakit kanker. Fungsi lain kurkumin adalah sebagai antioksidan karena mengandung senyawa fenolik dan inhibitor melanogenesis. Secara umum kurkumin tidak berdiri sendiri melainkan tetapi ada campuran kurkuminoid. Komposisinya terdiri dari $77 \%$ kurkumin, $17 \%$ demetoksikurkumin, dan $6 \%$ bisdemetoksi kurkumin (Sugiharto et al, 2012 ; Susanto dan Winarno, 2018).

\section{SIMPULAN}

Penggunaan molagen pada berbagai dosis mampu meningkatkan pertumbuhan tanaman terutama tinggi tanaman, luas daun dan bobot brangkasan. Peningkatan bobot rimpang pada semua perlakuan dosis molagen menunjukan peningkatan yang signifikan. Penggunaan molagen dosis 200 $\mathrm{ml} /$ liter dan urea $300 \mathrm{~kg} / \mathrm{ha}$ dapat meningkatkan kadar kurkumin antara 2,2 sampai 2,7\%. Disarankan tanaman kunyit sebaiknya dipanen pada umur antara $8-12$ bulan agar mendapatkan kadar kurkumin yang tinggi.

\section{UCAPAN TERIMA KASIH}

Terima kasih disampaikan kepada PT. Indofood Sukses Makmur Tbk., yang membiayai penelitian ini dalam skema Program Indofood Riset Nugraha (IRN) tahun 2020-2021. Ucapan terima kasih juga disampaikan kepada Laboratorium Gizi Fakultas gizi Kesehatan masyarakat Universitas Airlangga yang membantu analisis kadar kurkumin, serta Fakultas Pertanian Universitas Tribhuwana Tunggadewi yang mendukung penuh penelitian ini.

\section{DAFTAR PUSTAKA}

Alfian, MS, dan H Purnamawati. 2019. Dosis dan waktu aplikasi pupuk kalium pada pertumbuhan dan produksi jagung manis di BBPP Batangkaluku Kabupaten Gowa Sulawesi Selatan. Bul. Agrohorti. 7(1): 8-15. 
Amanullah, A Iqbal, Irfanullah, and Z Hidayat. 2016. Potassium management for improving growth and grain yield of maize (Zea mays Jurnal Agrikultura 2019, 30 (2): 40-45 ISSN 0853-2885

Aan (2004). Pengaruh Waktu, Suhu dan Nisbah Bahan Baku Pelarut pada Ekstraksi Kurkumin dari Temulawak dengan Pelarut Aseton. Skripsi. Fakultas Matematika dan Ilmu Pengetahuan Alam, Institut Pertanian Bogor, Bogor

Hafsi, C, A Debez, and A Chedly. 2014. Potassium deficiency in plants: effects and signaling cascades. Acta Physiologiae Plantarum. 36(5): 10551070

Hermawati, T., 2007. Respon Tanaman Semangka (Citrullus vulgaris Schard.) Terhadap Pemberian Berbagai Dosis Abu Sabut Kelapa. Jurnal Agronomi Fakultas Pertanian Universitas Jambi. $11(2): 77-80$

Jamilah, Y. N., \& Marni, Y. (2013). Peranan Gulma Chromolaena odorata dan Sabut Kelapa sebagai Bahan Baku Pupuk Organik Cair Menggantikan Pupuk Kalium untuk Pertumbuhan dan Hasil Padi Ladang. Padang: Prosiding Semnas Politani Payakumbuh Sumatera Barat, 1(1), 99-106

Joe, B.; M. Vijaykumar and B.R. Lokesh, 2004.Biological properties of curcumin- cellular and molecular mechanisms of action. Critical Review in Food Science and Nutrition 44 (2) : $97-112$.

Kristina, Nova Natalini. 2007. Peluang Peningkatan Kadar Kurkumin pada Tanaman Kunyit dan Temulawak. Balai Penelitian Tanaman Obat dan Aromatik. http://balittro.litbang.deptan.g o.id/pdf/edisikhusus/2007.

Li, 1., F. Chen, D. Yao, J. Wang, N. Ding, and X. Liu. 2010. Balanced fertilizer for ginger production-why potassium is important. www.ipni.net, Better Crops. 94(1):25-27.

Mamondol M.R. dan Bunga, 2017.
Peningkatan hasil dan kualitas jagung pulut Melalui penggunaan pupuk abu sabut kelapa. Jurnal Adiwidia Volume 4 Nomor 1. Edisi Desember 2017. https://osf.io/preprints/inarxiv/qtc32/

Novianto, Effendy I., dan Aminurohman, 2020. Respon Pertumbuhan dan Hasil Tanaman Sawi (Brassica juncea L.) Terhadap Pupuk Organik Cair Hasil Fermentasi Sabut Kelapa. Jurnal Agroteknika 3(1): 35-41 (2020). https://doi.org/10.32530/agroteknika.v3 i1.67

Rahma S., Rasyid B., dan Jayadi M., 2019. Peningkatan Unsur Hara Kalium Dalam Tanah Melalui Aplikasi POC Batang Pisang Dan Sabut Kelapa. Jurnal Ecosolum Volume 8, Nomor 2, Tahun 2019.

http://journal.unhas.ac.id/index.php/eco solum/article/view/pdf

Rahmawan I.S., Arifin A.Z., dan Sulistyawati, 2019. Pengaruh Pemupukan Kalium Terhadap Pertumbuhan dan Hasil Kubis. Volume 3, Nomor 1, Juni 2019, Hal. 17-23.

Sari, S.Y. 2015. Pengaruh Volume Pupuk Organik Cair Berbahan Dasar Serabut Kelapa(Cocos nucifera) Terhadap Pertumbuhan dan Hasil Panen Sawi Hijau(Brassica juncea). USD Yogyakarta.

Sanyal, D. dan Dhar, P. P. 2006. Effect of mulching, nitrogen, and potassium level on growth, yield and quality of turmeric grown in red lateric soil. Plants with Unique Horticultura Potencial.

Sugiharto, A., Arif, S., Ahmad, and.Hamid M,, 2012. Efektivitas kurkumin sebagai antioksidan dan inhibitor melanin pada kultur sel B16-F1. Jurnal Berkala Penelitian Hayati, Vol. 17, pp. 173176, 2012.

Susanto dan Ermin Katrin Winarno, 2018. Penentuan Kadar Kurkumin dari Beberapa Tanaman Curcuma Setelah Iradiasi Gamma. Prosiding Seminar Nasional APISORA 2018. https://inis.iaea.org/collection/NCLColl 
ectionStore/_Public/51/070/51070249.p $\underline{\mathrm{df}}$

Umar, I., Haris, A., \& Gani, M. S. (2021). Pengaruh Pemberian Konsentrasi Pupuk Organik Cair (Poc) Terhadap Pertumbuhan Dan Produksi Tanaman Kubis (Brassica oleracea L.). AGrotekMAS Jurnal Indonesia: Jurnal Ilmu Pertanian, 2(1), 81-87. https://jurnal.fp.umi.ac.id/index.php/agr otekmas/article/view/146

Widodo, RA, D Saidi, dan D Mulyanto. 2018. Pengaruh berbagai formula pupuk bio organo mineral terhadap $\mathrm{N}, \mathrm{P}, \mathrm{K}$ tersedia tanah dan pertumbuhan tanaman jagung. Jurnal Tanah dan Air. 15(1): 10-21.

Wijaya R., M. Madjid B. Damanik, Fauzi, 2017. Aplikasi Pupuk Organik Cair dari Sabut Kelapa dan Pupuk Kandang Ayam Terhadap Ketersediaan dan Serapan Kalium serta Pertumbuhan Tanaman Jagung pada Tanah Inceptisol Kwala Bekala. Jurnal Agroekoteknologi, Vol.5.No.2, April 2017 (33): 249-255. https://talenta.usu.ac.id/joa/article/view/ $\underline{2519 / 1904}$ 